\title{
ANALISIS MOTIVASI DALAM MENINGKATKAN KINERJA PEGAWAI DI SEKRETARIAT DPRD KOTA BANDAR LAMPUNG
}

\author{
IDA FARIDA ${ }^{1}$, SITI DAHLIA ${ }^{2}$ \\ Fakultas Ilmu Sosial dan Politik, Jurusan Administrasi Publik, \\ Universitas Bandar Lampung Jl. Zainal Abidin Pagar Alam No. 26 \\ Bandar Lampung \\ Email: ida.farida@ubl.ac.id; siti.dahlia@studentubl.ac.id
}

Motivasi merupakan daya penggerak dari berbagai motif yang ada pada diri individu dan diarahkan pada tujuan tertentu. Kinerja pegawai sebagai seorang manusia individu dimana perilaku kerja menjadi sumber daya utama dalam mencapai tujuan organisasi yang diinginkan.Kinerja merupakan hasil sinergi dari sejumlah faktor. Identifikasi masalah di atas, semua faktor penyebab tidak mungkin untuk diteliti seluruhnya maka dapat dirumuskan permasalahan sebagai berikut: (1) Bagaimana Motivasi Dalam Meningkatkan Kinerja Pegawai di Sekretariat DPRD Kota Bandar Lampung (2) Aspek - aspek apa saja yang menghambat Motivasi Dalam Meningkatkan Kinerja Pegawai di Sekretariat DPRD Kota Bandar Lampung.

Model Penelitian Kualitatif berakar pada latar alamiah sebagai keutuhan, mengandalkan manusia sebagai alat penelitian, memanfaatkan metode kualitatif, mengadakan analisis data secara induktif, mengarahkan sasaran penelitiannya pada usaha menemukan teori dari-dasar, bersifat deskriptif, membatasi studi dengan fokus, memiliki seperangkat kriteria untuk memeriksa keabsahan data, rancangan penelitiannya bersifat sementara, dan hasil penelitiannya disepakati oleh kedua belah pihak: peneliti dan subjek penelitian

Motivasi di bagi menjadi dua yaitu motivasi internal merupakan motivasi yang bersumber dari dalam dan tidak dipengaruhi oleh rangsangan dari luar, atau dengan kata lain individu tersebut tidak dipengaruhi oleh aspek - aspek lingkungan. Motivasi eksternal suatu kebutuhan ataupun keinginan seseorang dapat berkembang sebagai akibat dari interaksi individu dengan lingkungannya.

Aspek Yang Menghambat Motivasi Pegawai Dalam Meningkatkan Kinerja di Sekretariat DPRD Kota Bandar Lampung yaitu (1) Tidak bersedia bekerja sama

(2) Selalu datang terlambat (3) Tidak menyelesaikan tugas tepat waktu (4) Selalu mengeluh dengan pekerjaan (5) Tidak mematuhi peraturan yang ada Aspek Yang Mendukung Motivasi Pegawai Dalam Meningkatkan Kinerja di Sekretariat DPRD Kota Bandar Lampung. Dengan adanya motivasi maka pegawai tersebut bisa menghasilkan kinerja yang baik dalam pekerjaannya, adapun aspek yang mendukung motivasi pegawai dalam meningkatkan kinerja, yaitu (1) Berfikir positif (2) Menunjukkan perhatian (3) Selalu menjaga sikap (4) Mempunyai motivasi 


\section{PENDAHULUAN}

\section{Latar Belakang Masalah}

Motivasi merupakan daya penggerak dari berbagai motif yang ada pada diri individu dan diarahkan pada tujuan tertentu. Untuk mempelajari suatu ilmu dengan baik dibutuhkan motivasi, sebab motivasi berkaitan dengan semangat dan kegairahan seseorang untuk melakukan sesuatu.

Motivasi timbul karena pegawai merasakan kebutuhan akan bekerja. Motivasi bisa datang dari dalam diri sendiri maupun dari luar. Motivasi dari dalam sering disebut dengan motivasi intrinsik, sedangkan motivasi dari luar disebut dengan motivasi ekstrinsik (Makmum, 2004 : 37). Motivasi intrinsic, pegawai dimulai dan diteruskan berdasarkan dorongan dari dalam diri sehingga pegawai dapat bekerja atas kesadaran diri sendiri.

Motivasi ekstrinsik tumbuh dari rangsangan luar atau dari pihak luar. Meskipun berasal dari luar, namun motivasi ekstrinsik tidak dapat di abaikan. Kadang kala pegawai mengalami perubahan kondisi psikologis yang menyebabkan menurunnya motivasi. Misalnya karena jenuh atau bosan, maka pegawai membutuhkan rangsangan dari luar untuk memulihkan dan membangkitkan motivasinya.

Berdasarkan hasil observasi dilapangan, diperoleh keterangan yang menggambarkan motivasi dalam meningkatkan kinerja pegawai masih belum sesuai dengan harapan disebabkan menurunnya semangat kerja pegawai di Sekretariat DPRD Kota Bandar Lampung.

Permasalahan yang dikemukakan di atas maka dalam penelitian ini di batasi pada faktor motivasi dan kinerja pegawai. Dua faktor ini menurut dugaan peneliti cukup kuat kaitannya dengan meningkatkan kerja pegawai oleh karena itu peneliti hanya memfokuskan motivasi dalam meningkatkan kinerja pegawai di Sekretariat DPRD Kota Bandar Lampung. 
Berdasarkan penjelasan dan latar belakang tersebut identifikasi masalah dalam penelitian ini adalah :

1. Motivasi kerja yang semakin menurun dan tidak tercapainya tujuan, visi dan misi institusi.

2. Berdasarkan keahlian kinerja pegawai sehingga mengakibatkan banyak pegawai yang kurang memahami pekerjaan yang diberikan.

3. Beban pekerjaan yang diberikan kepada pegawai tidak sesuai dengan kapasitas dan kemampuan pegawai sehingga banyak pekerjaan yang tidak selesai dengan tepat waktu.

\section{Rumusan Masalah}

Berdasarkan identifikasi masalah di atas, semua faktor penyebab tidak mungkin untuk diteliti seluruhnya maka dapat dirumuskan permasalahan sebagai berikut:

1. Bagaimana Motivasi Pegawai Dalam Meningkatkan Kinerja di Sekretariat DPRD Kota Bandar Lampung?

2. Aspek - aspek apa saja yang menghambat Motivasi Pegawai Dalam Meningkatkan Kinerja di Sekretariat DPRD Kota Bandar Lampung?

\section{Tujuan Penelitian}

Adapun tujuan dalam penelitian ini adalah :

a. Untuk mengetahui Motivasi Dalam Meningkatkan Kinerja Pegawai di Sekretariat DPRD Kota Bandar Lampung.

b. Untuk mengetahui aspek - aspek apa saja yang menghambat Motivasi Dalam Meningkatkan Kinerja Pegawai di Sekretariat DPRD Kota Bandar Lampung.

\section{Kajian Teori}

\section{Konsep Motivasi}

Motivasi dapat mempengaruhi apa yang kita kerjakan, kapan kita bekerja, dan bagaiamana cara kita bekerja (Schunk, 1995). Pegawai yang termotivasi mempelajari sebuah topik cenderung melibatkan diri dalam berbagai aktifitas yang diyakininya akan membantu dirinya bekerja, seperti memperhatikan 
pelajaran secara sesakma, secara mental mengorganisasikan dan menghafal materi yang harus dipelajari, mencatat untuk memfasilitasi aktivitas bekerja berikutnya, memeriksa level pemahamannya, dan meminta bantuan ketika dirinya tidak memahami materi tersebut (Zimmerman, 2000). Secara kolektif, berbagai aktivitas ini meningkatkan motivasi.

Pegawai yang tidak termotivasi untuk bekerja, usaha-usaha belajarnya cenderung tidak sistematis pegawai yang termotivasi untuk bekerja. Motivasi menghasilkan suatu hubungan resiprokal dengan pemelajaran; yakni, motivasi mempengaruhi pemelajaran dan kinerja, dan hal-hal yang dilakukan dan dipelajari oleh pegawai mempengaruhi motivasinya (Pintrich, 2003: 56).

Dari pengertian yang dikemukakan para ahli tersebut, dapat disimpulkan bahwa motivasi adalah suatu dorongan yang menggerakkan seseorang untuk melakukan kegiatan dan menimbulkan semangat dan gairah kerja yang mengarah pada tercapainya tujuan tertentu, sehingga dengan motivasi seseorang akan merasa terangsang untuk melakukan tindakan yang lebih dalam kegiatannya dengan aktifitasnya.

Motivasi merupakan keberhasilan seseorang untuk mencapai prestasi yang setinggi - tingginya. Seseorang yang mendapat rangsangan atau dorongan yang tinggi melakukan pekerjaan dengan penuh percaya diri dan bersemangat.

\section{Konsep Kinerja}

Performance atau kinerja merupakan hasil atau keluaran dari suatu proses (Nurlaila, 2010:71). Menurut pendekatan perilaku dalam manajemen, kinerja adalah kuantitas atau kualitas sesuatu yang dihasilkan atau jasa yang diberikan oleh seseorang yang melakukan pekerjaan (Luthans, 2005:165).

Pengertian kinerja (prestasi kerja) adalah hasil kerja secara kualitas dan kuantitas yang dicapai oleh seorang pegawai dalam melaksanakan tugasnya sesuai dengan tanggung jawab yang diberikan kepadanya. Menurut Sedarmayanti (2001:50): 
"Kinerja merupakan terjemahan dari performance yang berarti prestasi kerja, pelaksanaan kerja, pencapaian kerja, unjuk kerja atau penampilan kerja".

Sainsudifi (2005:159) menyebutkan bahwa: "Kinerja adalah tingkat pelaksanaan tugas yang dapat dicapai seseorang, unit atau divisi dengan menggunakan kemampuan yang ada dan batasan-batasan yang telah ditetapkan untuk mencapai tujuan organisasi perusahaan".

Dari pendapat tersebut menjelaskan bahwa pada dasarnya kinerja merupakan pencapaian daripada tugas yang dilakukan oleh seseorang yang dilaksanakan menurut kemampuannya sesuai ketentuan-ketentuan yang telah ditetapkan oleh perusahaan atau organisasi yang memberikan tugas atau kegiatan tersebut.

Berdasarkan pengertian tersebut dapat disimpulkan bahwa kinerja adalah penampilan yang melakukan, menggambarkan dan menghasilkan sesuatu hal, baik yang bersifat fisik dan non fisik yang sesuai dengan petunjuk, fungsi dan tugasnya yang didasari oleh pengetahuan, sikap dan keterampilan.

\section{METODE PENELITIAN}

\section{Desain Penelitian}

Model Penelitian Kualitatif berakar pada latar alamiah sebagai keutuhan, mengandalkan manusia sebagai alat penelitian, memanfaatkan metode kualitatif, mengadakan analisis data secara induktif, mengarahkan sasaran penelitiannya pada usaha menemukan teori dari-dasar, bersifat deskriptif, membatasi studi dengan fokus, memiliki seperangkat kriteria untuk memeriksa keabsahan data, rancangan penelitiannya bersifat sementara, dan hasil penelitiannya disepakati oleh kedua belah pihak: peneliti dan subjek penelitian (dalam Moleong, 2013:44). 


\section{Sumber Data}

Dalam pengumpulan data digunakan prosedur pengumpulan data yang terdiri dari:

1. Sumber data primer

Merupakan data yang diperoleh langsung dari obyek penelitian yang dikumpulkan dan diolah sendiri. Data yang diperlukan adalah data tentang Motivasi Dalam Meningkatkan Kinerja Pegawai. Dimana data ini akan diperoleh dengan teknik wawancara kepada Pegawai yang ada di Sekretariat DPRD Kota Bandar Lampung.

2. Sumber data sekunder Merupakan pengumpulan data yang dilakukan dengan cara membaca, mempelajari, mengutip, serta menelaah literatur, arsip, artikel, dokumen, dan bahan penunjang lainnya yang berhubungan dengan permasalahan yang akan di teliti.

\section{Teknik Pengumpulan Data}

Teknik pengumpulan data yang digunakan dalam penelitian ini adalah:

1. Penelitian Kepustakaan ( Library research)

Pada sumber data ini, digunakan untuk mendapatkan konsep-konsep dan teori guna menunjang penelitian ini. Yang di dapat dari berbagai sumber bacaan, seperti buku, karya ilmiah, internet.

2. Penelitian Lapangan (Field research)

Merupakan pengumpulan data dan informasi yang dilakukan secara langsung dengan turun ke lapangan tempat obyek penelitian berada, dengan cara:

a. Observasi

Marshall (dalam Sugiyono, 2013:226) menyatakan bahwa " through observation, the researcher learn about behaviour and the meaning attached to those behaviour". Melalui observasi, peneliti belajar tentang perilaku, dan makna dari perilaku tersebut.

Alasan peneliti melakukan observasi adalah untuk menyajikan gambaran realistik perilaku atau kejadian, untuk membantu mengerti perilaku manusia, dan 
untuk evaluasi yaitu melakukan pengukuran terhadap aspek tertentu melakukan umpan balik terhadap pengukuran tersebut.

b. Interview (wawancara)

Wawancara merupakan alat re-cheking atau pembuktian terhadap informasi atau keterangan yang diperoleh sebelumnya. Tehnik wawancara yang digunakan dalam penelitian adalah wawancara mendalam. Wawancara mendalam (in-depth interview) adalah proses memperoleh keterangan untuk tujuan penelitian dengan cara tanya jawab sambil bertatap muka antara pewawancara dengan informan atau orang yang diwawancarai, dengan atau tanpa menggunakan pedoman (guide) wawancara, di mana pewawancara dan informan terlibat dalamnya. Wawancara dapat langsung kepada Pegawai di Sekretariat DPRD Kota Bandar Lampung.

c. Dokumentasi

Merupakan metode pengumpulan data dengan melihat atau menganalisis dokumen-dokumen yang dibuat oleh subjek sendiri atau oleh orang lain tentang subjek.

\section{Unit Analisis}

\section{Subjek Penelitian}

1. Pegawai di Sekretariat DPRD Kota Bandar Lampung

\section{Informan Penelitian}

1. Kabag Umum ( 1 orang )

2. Kepegawaian Sekretariat DPRD Kota Bandar Lampung (1 orang)

3. Pegawai Sekretariat DPRD Kota Bandar Lampung ( 2 orang) 


\section{HASIL PENELITIAN DAN PEMBAHASAN}

\section{Hasil Penelitian dan Pembahasan}

\section{Analisis Motivasi Pegawai Dalam Meningkatkan Kinerja Pegawai di Sekretariat DPRD Kota Bandar Lampung}

\section{a) Analisis Dorongan Internal}

Dorongan internal berasal dari dalam diri seseorang sering disebut motif, motif tersebut muncul sebagai akibat dari keinginan pemenuhan kebutuhan yang tidak terpuaskan, dimana kebutuhan tersebut muncul sebagai dorongan alamiah (naluri). Ini berarti kebutuhan tersebut menggerakkan perilaku seseorang seolah - olah karena tuntutan fisik dan psikologis yang muncul melalui mekanisme sistem secara biologis manusia.

Sesuai hasil observasi adanya dorongan internal dalam motivasi pegawai di Sekretariat DPRD Kota Bandar Lampung. Hal ini dilakukan karena sangatlah penting didalam kompetensi. Sesuai hasil wawancara dengan Kasubbag di Sekretariat DPRD Kota Bandar Lampung ditarik satu kesimpulan yang mengemukakan bahwa : "Adanya dorongan motivasi internal dari dalam diri pegawai, karena motivasi berperan penting dalam menciptakan prestasi kerja. Dengan memotivasi diri sendiri, pegawai akan terpacu untuk bekerja lebih giat lagi, banyak perlakuan yang dapat dilakukan dalam meningkatkan motivasi internal. Salah satunya dengan memberikan penghargaan kepada pegawai yang berprestasi. (Wawancara Desember 2017)",

Motivasi internal yang harus dipunyai atau dimiliki oleh setiap pegawai, karena itu adalah salah satu dorongan untuk motivasi demi meningkatkan kinerja pegawai di Sekretariat DPRD Kota Bandar Lampung.

Sesuai hasil wawancara dengan Kabag di Sekretariat DPRD Kota Bandar Lampung ditarik satu kesimpulan yang mengemukakan bahwa : "Dengan memotivasi diri sendiri, pegawai akan terpacu untuk bekerja lebih giat lagi, banyak perlakuan yang dapat dilakukan dalam meningkatkan motivasi internal. 
Salah satunya dengan memberikan penghargaan kepada pegawai yang berprestasi. (Wawancara Desember 2017 )"

Sesuai hasil wawancara dengan Pegawai di Sekretariat DPRD Kota Bandar Lampung ditarik satu kesimpulan yang mengemukakan bahwa : "para pegawai mempunyai motivasi salah satunya motivasi internal yang ada pada diri setiap pegawai, karena dengan adanya motivasi yang tumbuh pada para pegawai dapat meningkatkan kinerja pegawai dalam menyelesaikan tugas - tugas yang diberikan oleh pimpinan. (Wawancara Desember 2017)"

Menurut penulis motivasi internal merupakan motivasi yang bersumber dari dalam dan tidak dipengaruhi oleh rangsangan dari luar, atau dengan kata lain individu tersebut tidak dipengaruhi oleh aspek - aspek lingkungan. Beberapa contoh dari motivasi internal yaitu keinginan untuk memenuhi kebutuhan fisiologis, keinginan untuk lebih berkembang, rasa puas atau rasa bangga, pengakuan diri, pemahaman akan pekerjaan, pekerjaan yang menantang, tanggung jawab, dan lain - lain. Dalam pelaksanaan ini Pegawai Sekretariat DPRD Kota Bandar Lampung, bahwa pegawai di Sekretariat DPRD Kota Bandar Lampung sehingga harus lebih ditanamkan terhadap sesama pegawai di lingkup Sekretariat DPRD Kota Bandar Lampung.

\section{b) Analisis Dorongan Eksternal}

Motivasi eksternal menjelaskan kekuatan yang ada dalam individu yang dipengaruhi oleh faktor internal dari dalam diri pegawai, motivasi eksternal meliputi faktor pengendalian oleh pimpinan yang meliputi hal - hal yang berkaitan dengan pekerjaan

Seperti halnya gaji / upah, kebijakan dalam pekerjaan yang mengandung seperti penghargaan, pengembangan dan tanggung jawab, pimpinan disini harus lebih mengenal motivasi eksternal untuk mendapatkan tanggapan yang lebih positif dari pegawai. 
Sesuai hasil observasi adanya dorongan eksternal dalam motivasi pegawai di Sekretariat DPRD Kota Bandar Lampung. Hal ini dilakukan karena sangatlah penting didalam kompetensi. Sesuai hasil wawancara dengan Kasubbag di Sekretariat DPRD Kota Bandar Lampung ditarik satu kesimpulan yang mengemukakan bahwa : "Dengan adanya dorongan eksternal dalam motivasi pegawai mendapatkan tanggapan yang sangat positif bahwa pegawai sedang bekerja demi kemajuan di Sekretariat DPRD Kota Bandar Lampung. ( Wawancara Desember 2017) “

Sesuai hasil wawancara dengan Kabag di Sekretariat DPRD Kota Bandar Lampung ditarik satu kesimpulan yang mengemukakan bahwa "Adanya dorongan eksternal yang terdapat dalam motivasi pegawai mendapatkan tanggapan yang sangat positif di Sekretariat DPRD Kota Bandar Lampung. ( Wawancara Desember 2017) “

Sesuai hasil wawancara dengan Pegawai di Sekretariat DPRD Kota Bandar Lampung ditarik satu kesimpulan yang mengemukakan bahwa : " Motivasi eksternal pegawai sangat berguna dan mempunyai hasil positif bagi pegawai yang sedang bekerja demi kemajuan dan kesuksesan di Sekretariat DPRD Kota Bandar Lampung. ( Wawancara Desember 2017 ) “

Menurut penulis dalam kenyataannya suatu kebutuhan ataupun keinginan seseorang dapat berkembang sebagai akibat dari interaksi individu dengan lingkungannya, sebagai contoh seseorang yang tidak memiliki motif berprestasi yang tinggi dapat berubah ketika orang tersebut berada dalam lingkungan kelompok kerja dimana prestasi individu sangat dihargai ini akan mengakibatkan munculnya motif berprestasi yang tinggi.

Dalam pelaksanaan ini Pegawai Sekretariat DPRD Kota Bandar Lampung, bahwa pegawai di Sekretariat DPRD Kota Bandar Lampung sehingga harus lebih ditanamkan terhadap sesama pegawai di lingkup Sekretariat DPRD Kota Bandar Lampung. 


\section{Aspek Yang Menghambat Motivasi Pegawai Dalam Meningkatkan Kinerja di Sekretariat DPRD Kota Bandar Lampung.}

Pegawai yang tidak mempunyai motivasi tidak selalu mudah karena tidak ada dorongan yang terjadi dari dalam diri dan dorongan dari orang lain, adanya aspek yang menghambat yang terjadi pada motivasi pegawai dalam meningkatkan kinerja adalah

(1) Tidak bersedia bekerja sama

Produktivitas kerja di kantor ternyata juga ditentukan oleh gender. Meski saat ini telah banyak didengungkan mengenai kesetaraan gender, namun pekerjaan pria dan wanita tentunya tidak bisa disamakan. Bahkan berdasarkaan statistik menunjukkan banyak dari mereka yang memilih untuk berhenti atau merasa tertekan karena tidak bisa menyamai pekerjaan lawan jenisnya.

Penelitian menunjukkan bahwa banyak pegawai yang mundur bukan karena kemampuan yang dimilikinya kurang, melainkan karena mereka merasa tidak sanggup untuk menghadai pawan jenis di kantor.

(2) Selalu datang terlambat

Banyak pegawai yang datang terlambat terkadang tidak semua pegawai, tetapi ada pimpinan yang datang terlambat ke kantor. Disitu menunjukkan bahwa kurang disiplinya pegawai dan pimpinan yang seharusnya menjadi contoh yang baik kepada pegawai, ini memberikan contoh yang buruk yang dicontoh dan dikuti pegawai.

(3) Tidak menyelesaikan tugas tepat waktu

Para pegawai sering mendunda - nunda tugas yang diberikan dengan segala hal yang membuat pekerjaan menjadi kurang baik, dan hal ini menunjukkan tidak ada motivasi dalam menyelesaikan pekerjaan sehingga menghambat kinerja pegawa.

(4) Selalu mengeluh dengan pekerjaan

Terkadang pegawai merasakan jenuh kepada pekerjaan yang diberikan kepadanya oleh pimpinan, dengan rasa mengeluh kepada pegawai yang lain. 
Seharusnya pimpinan bisa mengerti keadaan pegawai yang jangan terlalu diporsir didalam pekerjaannya.

(5) Tidak mematuhi peraturan yang ada

Banyak pegawai yang tidak mematuhi peraturan yang berlaku, walau sudah dipasang banner tulisan 10 Budaya Malu yang terpampang jelas dipintu masuk. Tetapi masih saja pegawai yang melanggar peraturan itu.

\section{Aspek Yang Mendukung Motivasi Pegawai Dalam Meningkatkan Kinerja di Sekretariat DPRD Kota Bandar Lampung.}

Pegawai yang mempunyai motivasi tinggi dalam melakukan tugas akan bisa meningkatkan kinerja pegawai ini, pada setiap pegawai harus memiliki motivasi pada dirinya sendiri. Dengan adanya motivasi maka pegawai tersebut bisa menghasilkan kinerja yang baik dalam pekerjaannya, adapun aspek yang mendukung motivasi pegawai dalam meningkatkan kinerja, yaitu :

(1) Berfikir positif

(2) Menunjukkan perhatian

(3) Selalu menjaga sikap

(4) Mempunyai motivasi

Produktivitas mempunyai arti perbandingan antara output dan input, jadi produktivitas naik mungkin oleh adanya peningkatan efisiensi (waktu, bahan, tenaga) dan sistem kerja, teknik produksi, dan adanya peningkatan keterampilan dan tenaga kerja.

Sesuai hasil observasi adanya motivasi dalam kinerja pegawai di Sekretariat

DPRD Kota Bandar Lampung. Hal ini dilakukan karena sangatlah penting didalam meningkatkan kinerja pegawai.

Sesuai hasil wawancara dengan Kasubbag di Sekretariat DPRD Kota Bandar Lampung ditarik satu kesimpulan yang mengemukakan bahwa : "Produktivitas dalam kinerja pegawai di Sekretariat DPRD Kota Bandar Lampung sudah secara maksimal terlaksana guna menunjang tugas pokok dan fungsi Sekretariat Dewan sebagai unsur pelayanan terhadap DPRD. (Wawancara Desember 2017) “ 
Sesuai hasil wawancara dengan Kabag di Sekretariat DPRD Kota Bandar Lampung ditarik satu kesimpulan yang mengemukakan bahwa : "Produktivitas kinerja merupakan hasil yang diperoleh dari pekerjaan - pekerjaan yang dilaksanakan oleh para pegawai.(Wawancara Desember 2017) “

Sesuai hasil wawancara dengan Pegawai di Sekretariat DPRD Kota Bandar Lampung ditarik satu kesimpulan yang mengemukakan bahwa : "Para pegawai dapat menunjukkan hasil kerja yang merupakan prestasi kerja pegawai dalam melaksanakan tugas - tugasnya, dapat dilihat dari jumlah frekuensi diatas standar yang telah ditetapkan, hal ini juga menandakan bahwa pegawai tersebut produktif didalam menyelesaikan pekerjaannya. (Wawancara Desember 2017 ) “

Menurut penulis pentingnya peningkatan produktivitas disebabkan karena adanya kenyataan bahwa tingkat produktivitas yang tinggi, dan pada produktivitas kerja sebagai aksentuasi penerapan motif ekonomi yang banyak terletak pada faktor manusia pelaksanaan kegiatan itu sendiri yaitu para anggota, pegawai atau pelaksana, sehingga instansi atau organisasi selalu berupaya agar pegawai selalu terlibat untuk mengembangkan dirinya. Dalam pelaksanaan ini Pegawai Sekretariat DPRD Kota Bandar Lampung, bahwa pegawai di Sekretariat DPRD Kota Bandar Lampung sehingga harus lebih ditanamkan terhadap sesama pegawai di lingkup Sekretariat DPRD Kota Bandar Lampung.

Sesuai hasil wawancara dengan Kasubbag di Sekretariat DPRD Kota Bandar Lampung ditarik satu kesimpulan yang mengemukakan bahwa :

“ Pelayanan pegawai di Sekretariat DPRD Kota Bandar Lampung sesuai dengan standar SOP dalam hal pelayanan terhadap anggota DPRD Kota Bandar Lampung. (Wawancara Desember 2017) “

Sesuai hasil wawancara dengan Kabag di Sekretariat DPRD Kota Bandar Lampung ditarik satu kesimpulan yang mengemukakan bahwa : "Dalam pelayanan yang diberikan pegawai kepada anggota Dewan masih mengikuti 
standar SOP yang berlaku di Sekretariat DPRD Kota Bandar Lampung. (Wawancara Desember 2017) “

Sesuai hasil wawancara dengan Pegawai di Sekretariat DPRD Kota Bandar Lampung ditarik satu kesimpulan yang mengemukakan bahwa :"Dalam hal pelayanan kami (pegawai) selalu berusaha memberikan pelayanan yang baik dan masih mgikuti aturan pelayanan yang ada dalam SOP. (Wawancara Desember 2017) “

Menurut penulis bahwa kualitas pelayanan yang diberikan sudah cukup baik dan sesuai harapan, dimana pelayanan dikatakan berkualitas apabila seluruh pelayanan sesuai dengan kebutuhan atau SOP dan harapan, dalam hal ini kualitas pelayanan pada dasarnya pelayanan yang baik itu adalah sikap atau cara pegawai dalam melayani anggota Dewan secara memuaskan. Reponsivitas dalam salah satu konsep yang digunakan dalam pengukuran kinerja sangat dibutuhkan, hal tersebut merupakan bukti kemampuan pegawai untuk mengenali kebutuhan para dewan, menyusun agenda, dan prioritas pelayanan serta mengembangkan program program yang sesuai dengan kebutuhan.

Sesuai hasil wawancara dengan Kasubbag di Sekretariat DPRD Kota Bandar Lampung ditarik satu kesimpulan yang mengemukakan bahwa :

"Kemampuan pegawai dalam mengenali kebutuhan anggota DPRD dalam menyusun agenda dan prioritas pelayanan serta mengembangkan program program sesuai dengan kebutuhan dan aspirasi anggota Dewan. (Wawancara Desember 2017) “

Sesuai hasil wawancara dengan Kabag di Sekretariat DPRD Kota Bandar Lampung ditarik satu kesimpulan yang mengemukakan bahwa :

"Responsivitas sangat diperlukan karena hal tersebut merupakan bukti kemampuan pada pegawai . (Wawancara Desember 2017) “

Sesuai hasil wawancara dengan Pegawai di Sekretariat DPRD Kota Bandar Lampung ditarik satu kesimpulan yang mengemukakan bahwa :"Responsivitas 
merupakan cara pegawai yang efesien dalam mengatur program - program pelayanan terhadap para anggota Dewan. (Wawancara Desember 2017) “

Menurut penulis reponsivitas yang terjadi di Sekretariat DPRD Kota Bandar Lampung menunjukkan bahwa para pegawai memberikan pelayanan dengan baik atau masih sesuai dengan SOP, tidak ada yang dibeda - bedakan antara anggota Dewan yang satu dengan yang lain tetapi tergantung jabatan anggota Dewan masing - masing.

Tanggung jawab seseorang terhadap tugas - tugasnya yang berhubungan dengan peran seseorang kepada pihak yang dilayani, kewajiban - kewajiban dari individu atau pemimpin yang dipercayakan untuk mengelola sumber daya publik yang bersangkutan dengannya untuk dapat menjawab hal - hal yang menyangkut pertanggung jawaban.

Sesuai hasil wawancara dengan Kasubbag di Sekretariat DPRD Kota Bandar Lampung ditarik satu kesimpulan yang mengemukakan bahwa : "Dalam kinerja pegawai kemampuan para pegawai dalam melaksanakan kegiatan - kegiatannya semua dipertanggung jawabkan oleh pegawai tersebut. (Wawancara Desember 2017) “

Sesuai hasil wawancara dengan Kabag di Sekretariat DPRD Kota Bandar Lampung ditarik satu kesimpulan yang mengemukakan bahwa :

"Responsibilitas pelayanan pegawai terhadap anggota dewan dapat dilihat dan proses kecepatan dan ketepatan dalam penyelesaian pekerjaan yang ada. (Wawancara Desember 2017) “

Sesuai hasil wawancara dengan Pegawai di Sekretariat DPRD Kota Bandar Lampung ditarik satu kesimpulan yang mengemukakan bahwa : "Kemampuan para pegawai dalam melaksanakan kegiatan - kegiatannya semua dipertanggung jawabkan dapat dilihat dan proses kecepatan dan ketepatan dalam penyelesaian pekerjaan yang ada. (Wawancara Desember 2017) “ 
Menurut penulis bahwa sikap reponsibilitas yang terdapat pada pegawai sudah cukup bagus walau masih ada pegawai yang mangkir dari tanggung jawab yang diberikan oleh pimpinan kepada pegawai tersebut, sehingga harus ditetapkan sikap tanggung jawab pada diri setiap para pegawai.

Sesuai hasil wawancara dengan Kasubbag di Sekretariat DPRD Kota Bandar Lampung ditarik satu kesimpulan yang mengemukakan bahwa : "Pada dasarnya akuntabilitas mengkomunikasikan kinerja dengan rencana kinerja sebagai tolak ukur keberhasilan. (Wawancara Desember 2017) “

Sesuai hasil wawancara dengan Kabag di Sekretariat DPRD Kota Bandar Lampung ditarik satu kesimpulan yang mengemukakan bahwa : “Akuntabilitas capaian kinerja terhadap rencana kinerja akan memungkinkan identifikasinya sejumlah celah kinerja bagi perbaikan kinerja dimasa yang akan datang. (Wawancara Desember 2017) “

Sesuai hasil wawancara dengan Pegawai di Sekretariat DPRD Kota Bandar Lampung ditarik satu kesimpulan yang mengemukakan bahwa : Akuntabilitas yang ada pada pegawai belum semuanya bisa melakukan itu, sehingga terkadang kinerja yang dihasilkan belum terlalu baik. (Wawancara Desember 2017) “

Menurut penulis bahwa reponsibilitas yang terdapat pada pegawai di Sekretariat DPRD Kota Bandar Lampung ini belum sesuai karena masih banyak pegawai yang mengacuhkan hal tersebut.

\section{Kesimpulan}

Berdasarkan hasil penelitian dan pembahasan maka dapat ditarik kesimpulan, yaittu:

1. Motivasi di bagi menjadi dua yaitu motivasi internal merupakan motivasi yang bersumber dari dalam dan tidak dipengaruhi oleh rangsangan dari luar, atau dengan kata lain individu tersebut tidak dipengaruhi oleh aspek - aspek lingkungan. Motivasi eksternal suatu kebutuhan ataupun keinginan seseorang 
dapat berkembang sebagai akibat dari interaksi individu dengan lingkungannya.

2. Aspek Yang Menghambat Motivasi Pegawai Dalam Meningkatkan Kinerja di Sekretariat DPRD Kota Bandar Lampung yaitu (1) Tidak bersedia bekerja sama (2) Selalu datang terlambat (3) Tidak menyelesaikan tugas tepat waktu (4) Selalu mengeluh dengan pekerjaan (5) Tidak mematuhi peraturan yang ada Aspek Yang Mendukung Motivasi Pegawai Dalam Meningkatkan Kinerja di Sekretariat DPRD Kota Bandar Lampung. Dengan adanya motivasi maka pegawai tersebut bisa menghasilkan kinerja yang baik dalam pekerjaannya, adapun aspek yang mendukung motivasi pegawai dalam meningkatkan kinerja, yaitu (1) Berfikir positif (2) Menunjukkan perhatian (3) Selalu menjaga sikap (4) Mempunyai motivasi

\section{DAFTAR PUSTAKA}

Abin Syamsuddin. M. 2004. Motivasi. Jakarta : PT. Gunung Agung.

Arikunto, Suharsimi, 2006. Prosedur Penelitian Suatu Pendekatan Praktek, Jakarta, Rineka Cipta.

Blumberg \& Pringle. 1982. Teknik dan Strategi Memasarkan Jasa Profesional.

Cetakan Pertama. Alih Bahasa Wilhelmus W. Bauwaton.

Casio T. 2000, Teori dan Praktek Kinerja, Jakarta, Rineka Cipta.

Dakarsih, 1997. 10 Prinsip Kepuasan Pelanggan, Jakarta: P.T. Elex Media

Kompotindo.

Dale H. Schunk. 2008. Motivasi dalam Pendidikan. Jakarta; Indeks

Dessler. 2004. Kinerja Pegawai. Jakarta : Rajawali Pers

Donnelly. Et. A1. 2003, Elemen-Elemen Penting Dalam Sistem Pengupahan, Terjemahan : Hasan, Jakarta, Yayasan Obor Indonesia.

Dwiyanto, 2006, Pengukuran Kualitas Pelayanan Administrasi Penanaman Modal di Kabupaten Garut. 
Elizur. D. Barg. Dkk. 1996. Sistem Manajemen Kinerja Terintegrasi: Balanced Scorecard dengan Six Sigma untuk Organisasi Bisnis dan Pemerintah. Ed. 1, 2. Jakarta: PT.Gramedia Pustaka Utama.

Gibson. 1996. Pola Dasar Kepemimpinan. Jakarta : Rajawali Pers

Griffin, 2002, Konsep Kinerja dan Pendekatan Manusiawi, Jakarta, Rineka Cipta.

Hadari Nawawi. 1996. Metodologi Penelitian. Bandung: Grafindo

Hasibuan, S.P. Malayu, 2000 Organisasi dan Motivasi, Jakarta, PT. Bumi Aksara. Hutauruk. 1986. Teori Kinerja. Jakarta : Gramedia.

Jacobus, 2001, Kinerja, Jakarta, LP3ES

Joner. 2002. Konsep Kinerja. Yogyakarta : Pembaruan

Luthans, 2005., Sosiologi Pembangunan Pedesaan, Jakarta, Bina Aksara. Mangkunegara,2002, Faktor-Faktor yang Mempengaruhi Produktivitas Karyawan, Ujung Pandang : Unhas Press.

Mathis L. and Jhon H.Jackson, 2001, Manajemen Sumberdaya Manusia (Human Resource Management), Jakarta, PT. Salemba Emban Patria.

Mohammad Natsir. 1999. Metode Penelitian. Jakarta: Ghalia Indonesia.

Moleong. 2013. Metode Penelitian Sosial. Jakarta: Rajawali Kurnia.

Nulaila, 2010, Kinerja, STIE., Yogyakarta, YKPN.

Pintrich, 2003, Pengaruh Upah Terhadap Motivasi Kerja Karyawan, Yogyakarta, UGM. Press

Prawirosentono, 1999. Pembinaan Kinerja Pegawai Negeri Sipil. Bina Aksara. Jakarta.

Richard M. 2005, Prinsip-Prinsip Total Quality Service, Yogyakarta, Andi.

Rivai, 2005. Kinerja Pegawai, Terjemahan Erli Swandy, Jakarta, Salemba Empat.

Robbins, 2003. Interaksi dan Motivasi Belajar Mengajar, Jakarta, PT. Raja Grafindo

Sainsudifi, 2005. Produktivitas dan Tenaga kerja Indonesia, Lembaga Sarana Informasi Usaha dan Produktivitas, Jakarta.

Sedarmayanti, 2001, Sumberdaya Manusia dan Kinerja, Bandung, Mandar Maju. Sihotang, 2007, Membangun Motivasi Kerja, Jakarta, Media Asri. 
Sinambela, 2016, Aplikasi Kinerja. Jakarta : Erlangga.

Stoner, 2006. Karakteristik Motivasi. Bandung : PT. Refika Aditama.

Stolovitch \& Keeps. 2000. Managing Services : Marketing, Operations, And Human resources. Second Edition. Prentice Hall, Englewood Cliffs, New Jersey.

Sugiyono, 2005, Metode Penelitian Administrasi, Bandung : Alfabeta

Timpe Dale, 2000, Seri Manajemen Sumberdaya Manusia, Memimpin Manusia, Jakarta, PT. Elex Media Komputindo.

Winardi, 2002. Teori Motivasi. Bandung : Indomedia.

Wiraman., 2016. Motivasi Kinerja. Yogyakarta : Pembaruan.

Zimmerman. 2000. Motivasi Belajar. Yogyakarta: Kanisius 